

\title{
PENGARUH STRATEGI DIRECTED LISTENING THINKING ACTIVITY (DLTA) BERBANTUAN MEDIA AUDIO VISUAL TERHADAP KEMAMPUAN MENYIMAK DONGENG
}

\section{Riga Zahara Nurani}

Universitas Perjuangan Tasikmalaya

\section{Sejarah Artikel}

Diterima 1 September 2017

Disetujui 1 Oktober 2017

Diterbitkan 1 Desember 2017

\section{Kata Kunci}

Kemampuan menyimak

dongeng, Strategi Directed

Listening Thinking Activity

(DLTA), Unsur-unsur intrinsik

\begin{abstract}
Abstrak
Dalam pembelajaran menyimak, siswa harus memahami unsur-unsur intrinsik dongeng yang meliputi tokoh, latar, tema, alur, dan amanat. Pembelajaran menyimak di sekolah biasanya tidak merangsang siswa untuk berpikir kritis, karena guru hanya membaca dongeng di depan kelas sementara siswa mendengarkan. Oleh karena itu diperlukan strategi pembelajaran yang mampu merangsang siswa berpikir kritis, salah satunya adalah strategi Directed Listening Thinking Activity (DLTA). Selain itu, penggunaan media audio visual juga diperlukan agar pembelajaran lebih bermakna. Penelitian ini dilakukan di kelas V SDN 6 Singaparna Kabupaten Tasikmalaya. Pada kelas eksperimen diterapkan strategi Directed Listening Thinking Activity (DLTA) berbantuan media audio visual, sedangkan pada kelas kontrol diterapkan pembelajaran langsung. Rata-rata kemampuan menyimak dongeng kelas eksperimen sebelum diberi perlakuan adalah 67,20 dan setelah diberi perlakuan meningkat menjadi 84,53. Sedangkan rata-rata kemampuan menyimak dongeng kelas kontrol sebelum diberi perlakuan adalah 67,26 dan setelah diberi perlakuan menjadi 77,55. Berdasarkan hasil Uji-t menggunakan SPSS 22 diperoleh thitung $=4,445$ dan pada $\alpha=$ 0,05 , df $=59$ dan uji (1-tailed) maka diperoleh tkritis $=1,671$. Karena thitung $>$ tkritis, maka $\mathrm{H}_{0}$ ditolak. Kesimpulannya, terdapat perbedaan skor kemampuan menyimak dongeng kelas eksperimen dan kelas kontrol. Dengan demikian, strategi Directed Listening Thinking Activity (DLTA) berpengaruh positif terhadap kemampuan menyimak dongeng siswa.
\end{abstract}

\section{Cara Mengutip}

Nuraini, R.Z. (2017). Pengaruh Strategi Directed Listening Thinking Activity (DLTA) Berbantuan Media Audio Visual terhadap Kemampuan Menyimak Dongeng. DWIJACENDEKIA Jurnal Riset Pedagogik, 1(2), 79-86.
Korespondensi Penulis: rigazn@gmail.com
p-ISSN 2581-1843

e-ISSN 2581-1835 


\section{PENDAHULUAN}

Pendidikan merupakan aspek Menyimak adalah keterampilan berbahasa yang pertama kali dikembangkan oleh seseorang untuk melakukan komunikasi. Dengan menyimak, seseorang mampu mengembangkan keterampilan berbahasa lainnya seperti berbicara, membaca, dan menulis. Dalam proses menyimak, terdapat pesan yang disampaikan secara lisan oleh pembicara atau pemberi pesan kepada pendengar atau penerima pesan. Proses menyimak berbeda dengan proses mendengarkan. Dalam menyimak, terdapat usaha untuk memahami bahan dari simakan atau pesan yang disampaikan. $\mathrm{Hal}$ ini berbeda dengan mendengarkan yang mungkin saja tidak ada kesengajaan untuk memahami apa yang disimak.

Pembelajaran menyimak di sekolah dasar sudah diajarkan secara formal di dalam kelas. Salah satu pembelajaran menyimak yang sering diajarkan adalah menyimak dongeng. Dalam menyimak dongeng, siswa diharuskan memahami unsur-unsur intrinsik dongeng. Unsur-unsur intrinsik dongeng meliputi tokoh, tema, latar, alur, dan amanat. Tokoh merupakan pelaku atau pemain dalam sebuah dongeng. Latar merupakan sebuah keterangan mengenai tempat, waktu, dan suasana dongeng. Tema merupakan gambaran besar isi cerita dalam sebuah dongeng. Amanat merupakan pesan atau nilai moral yang terkandung dalam sebuah dongeng. Sedangkan alur merupakan runtutan cerita atau rangkaian peristiwa dan konflik yang menggerakkan jalan cerita sebuah dongeng.
Selain memahami unsur-unsur yang terdapat di dalam sebuah dongeng, anak juga diharapkan mampu mengingat isi dongeng atau alur cerita sebuah dongeng. Dengan mengetahui dan mengingat isi dongeng, anak bisa menceritakan kembali dongeng yang telah didapatkannya kepada temantemannya atau kepada generasi mendatang. Sebuah dongeng harus diwariskan secara turun temurun agar nilai moral yang terkandung dalam dongeng bisa disebarluaskan dan tidak terhenti pada satu generasi. Oleh sebab itu, ada baiknya pendongeng dalam hal ini guru maupun orang tua me-review apakah anak sudah memahami dan mengingat isi dongeng ataukah belum.

Untuk menciptakan pembelajaran yang aktif, guru harus mampu menggunakan strategi pembelajaran yang inovatif. Penggunaan strategi pembelajaran Direct Listening Thinking Activity (DLTA) bisa menjadi salah satu alternatif strategi pembelajaran menyimak dongeng. Pembelajaran menyimak dongeng dengan menggunakan strategi DLTA telah terbukti lebih baik daripada pembelajaran langsung. Hal ini sesuai dengan penelitian yang dilakukan oleh Septiadi, dkk (2014) menemukan bahwa kemampuan menyimak siswa yang menggunakan strategi DLTA memiliki mean $(M)=25$, sedangkan kemampuan menyimak siswa yang menggunakan pembelajaran langsung memiliki mean $(M)=15,33$. Adapun Langkah-langkah dalam penggunaan strategi ini adalah sebagai berikut (Tompkins \& Hoskisson, 1991):

1. Kegiatan sebelum menyimak 
Pada kegiatan ini, guru mengeksplorasi pengetahuan awal siswa, menyediakan informasi baru yang diperlukan oleh siswa tentang cerita, dan membangkitkan minat siswa untuk menyimak cerita yang akan dipaparkan.

2. Kegiatan selama menyimak

a. Memprediksi

Pada kegiatan ini, guru menyampaikan judul cerita yang akan disampaikan. Guru merangsang siswa untuk membuat prediksi tentang isi cerita yang akan disampaikan. Guru dapat membacakan satu atau dua paragraf isi cerita tersebut.

b. Memprediksi dan membuat alasan dari cerita yang telah dipaparkan

Ditengah-tengah cerita, guru menghentikan cerita dan kembali merangsang siswa untuk membuat prediksi kelanjutan cerita beserta alasannya.

c. Membuktikan
Siswa membuktikan prediksi yang telah ia buat sebelumnya.

3. Kegiatan setelah menyimak

Setelah kegiatan menyimak selasai dilakukan, siswa menyampaikan hasil bacaan mereka untuk didiskusikan, menghubungkan dengan kehidupan mereka dan dengan cerita yang telah dipaparkan sebelumnya.

Selain penggunaan strategi pembelajaran yang inovatif, penggunaan media pembelajaran juga berperan penting dalam kesuksesan proses pembelajaran. Media pembelajaran dapat membantu guru dalam rangka mencapai tujuan pembelajaran agar lebih optimal. Media pembelajaran yang bisa diterapkan dalam menyimak dongeng adalah media audio visual. Penggunaan media audio dalam keterampilan menyimak terbukti mampu meningkatkan kemampuan menyimak dongeng (Widyaningrum, 2015)

\section{METODE PENELITIAN}

Penelitian ini dilakukan di kelas $\mathrm{V}$ SDN 6 Singaparna Kabupaten Tasikmalaya. Desain penelitian yang digunakan adalah quasi eksperimen. Kelas eksperimen diterapkan strategi Direct Listening Thinking Activity (DLTA) berbantuan media audio visual dan kelas kontrol diterapkan pembelajaran langsung. Instrumen penelitian yang digunakan adalah soal prates dan soal pascates yang meliputi soal piliha ganda dan uraian. Soal prates dan pascates tidaklah sama, hal ini karena materi yang diberikanpun berbeda. Soal prates dan pascates dikembangkan dari kisikisi yang telah dibuat sebelumnya. Teknik analisis data menggunakan SPSS 22 untuk menguji normalitas, homogenitas, dan perbedaan ratarata.

\section{PEMBAHASAN}

\section{A. Hasil Penelitian}

1. Analisis hasil prates

Pemberian perlakuan kepada kelas eksperimen dan kelas kontrol dilakukan sebanyak 5 kali. Ratarata skor kemampuan menyimak dongeng kelas eksperimen adalah 67, 20 dan termasuk kategori 
cukup yang artinya siswa mampu memahami beberapa unsur-unsur intrinsik dongeng (tokoh, tema, latar, amanat, alur) dan mampu menceritakan kembali isi dongeng walaupun kurang mendetail. Ratarata skor kemampuan menyimak dongeng kelas kontrol adalah 67,26 dan juga masuk ke dalam kategori cukup.

Nilai signifikansi uji KolmogrovSmirnov pada skor prates kemampuan menyimak dongeng kelas eksperimen adalah 0,83 lebih besar dari $\alpha=0,05$, ini menunjukan bahwa data prates kelas eksperimen berdistribusi normal. Begitu juga dengan hasil uji Kolmogrov-Smirnov pada skor prates kemampuan menyimak dongeng kelas kontrol memiliki nilai signifikansi 0,69 lebih besar dari $\alpha=0,05$, ini menunjukan bahwa data prates kelas kontrol berdistribusi normal.

Nilai Sig. Based on Mean kemampuan menyimak dongeng kelas eksperimen dan kelas kontrol adalah 0,468 lebih besar dari $\alpha=$ 0,05 , sehingga $\mathrm{H}_{0}$ diterima. Hal ini berarti skor prates kemampuan menyimak dongeng kelas eksperimen dan kelas kontrol memiliki variansi yang homogen.

Uji perbedaan rata-rata skor prates dilakukan untuk membuktikan bahwa tidak ada perbedaan yang signifikan antara kemampuan awal kelas eksperimen dan kelas kontrol. Kemampuan menyimak dongeng nilai Sig. (2-tailed) adalah $0.990>0.05$, sehingga $\mathrm{H}_{0}$ diterima $\mathrm{H}_{1}$ ditolak. Hal ini berarti rata-rata prates kemampuan menyimak dongeng antara kelas eksperimen dan kelas kontrol memiliki rata-rata yang sama atau tidak ada perbedaan yang signifikan antara rata-rata kemampuan menyimak dongeng antara kelas eksperimen dan kelas kontrol.

\section{Analisis hasil pascates}

Nilai signifikansi uji KolmogrovSmirnov pada skor pascates kemampuan menyimak dongeng kelas eksperimen adalah 0,169 lebih besar dari $\alpha=0,05$, ini menunjukan bahwa data pascates kelas eksperimen berdistribusi normal. Begitu juga dengan hasil uji Kolmogrov-Smirnov pada skor pascates kemampuan menyimak dongeng kelas kontrol memiliki nilai signifikansi 0,149 lebih besar dari $\alpha=0,05$, ini menunjukan bahwa data pascates kelas kontrol berdistribusi normal.

Nilai Sig. Based on Mean kemampuan menyimak dongeng kelas eksperimen dan kelas kontrol adalah 0,723 lebih besar dari $\alpha=$ 0,05 , sehingga $\mathrm{H}_{0}$ diterima. Hal ini berarti skor pascates kemampuan menyimak dongeng kelas eksperimen dan kelas kontrol memiliki variansi yang homogen.

Uji perbedaan rata-rata skor pascates dilakukan untuk membuktikan apakah terdapat perbedaan yang signifikan antara kemampuan akhir kelas eksperimen dan kelas kontrol. Kemampuan menyimak dongeng pada $\alpha=0,05, \mathrm{df}=59$ dan uji (1tailed) maka diperoleh tkritis $=1,671$, karena thitung $=4,445$ terletak di daerah penolakan $\mathrm{H}_{0}$ maka $\mathrm{H}_{1}$ diterima. Hal ini berarti rata-rata pascates kemampuan menyimak dongeng antara kelas eksperimen 
dan kelas kontrol memiliki perbedaan

\section{Analisis kemampuan (N-Gain)}

Semua skor kemampuan menyimak dongeng kelas eksperimen mengalami peningkatan. Terdapat 4 orang siswa atau 13,33\% siswa mengalami peningkatan yang tinggi, 26 orang siswa atau 86,67\% siswa mengalami peningkatan yang sedang, dan tidak ada siswa yang mengalami peningkatan rendah. Sedangkan peningkatan skor kemampuan menyimak dongeng di kelas kontrol sangat beragam, bahkan ada 1 orang siswa yang mengalami penurunan. Berdasarkan kategori yang telah ditetapkan, tidak terdapat siswa yang mengalami peningkatan tinggi, 16 orang siswa mengalami peningkatan sedang, dan 15 orang siswa mengalami peningkatan rendah

\section{B. Pembahasan}

1. Pembelajaran Menyimak dengan Menggunakan Strategi Direct Listening Thinking Activity (DLTA)

Pelaksanaan

pembelaran

menyimak dengan menggunakan strategi DLTA secara keseluruhan sudah berjalan dengan baik. Hal ini karena guru kelas bertindak sangat kooperatif sehingga mampu memimpin pembelajaran sebagaimana mestinya. Sebelum melakukan pembelajaran menggunakan strategi DLTA, peneliti memberikan arahan terlebih dahulu kepada guru kelas mengenai strategi DLTA ini. Peneliti mendiskusikan mengenai RPP dan materi ajar yang akan diberikan pada siswa. Proses diskusi dan pengenalan ini dilakukan mulai tanggal $6-11$ Maret 2017, kemudian pada tanggal $13 \quad$ Maret 2017 dilaksanakan prates.

Pertemuan pertama pembelajaran menggunakan strategi ini adalah pada tanggal 20 Maret 2017. Materi ajar yang diberikan adalah dongeng yang berjudul "Kisah Pencuri yang Bertobat". Dongeng ini sebelumnya belum pernah didengar oleh siswa. Pemilihan dongeng ini sebagai materi ajar pada pembelajaran dengan strategi DLTA karena siswa harus menebak kelanjutan cerita, sehingga dongeng yang diberikan haruslah dongeng yang benarbenar baru dan belum familiar.

Pertemuan kedua pembelajaran menggunakan strategi DLTA adalah pada tanggal 23 Maret 2017. Materi yang diajarkan adalah dongeng yang berjudul "Kisah Raja Zalim dan Pemuda Shalih". Pembelajaran kedua sudah lebih kondusif daripada pembelajaran pertama. Siswa sudah mulai terbiasa belajar menggunakan infokus. Siswa duduk sesuai kelompoknya dan mendengarkan video dengan seksama. Guru juga sudah mulai terbiasa mengajar dengan strategi ini.

Pertemuan ketiga pembelajaran dengan strategi DLTA adalah pada tanggal 27 Maret 2017. Materi yang diajarkan adalah dongeng yang berjudul "Kisah Raja Jadi Tukang Kebun". Langkah pembelajaran dipertemuan ketiga ini hampir sama dengan pertemuan pertama dan kedua. 
Guru dan siswa sudah terbiasa belajar dengan strategi DLTA. Siswa lebih aktif mengutarakan idenya pada pertemuan ini.

Pertemuan keempat dilaksanakan pada tanggal 3 April 2017. Materi yang diajarkan adalah dongeng yang berjudul "Si Kusta". Guru dan siswa sudah sangat terbiasa belajar dengan strategi ini. Langkah pembelajaran di pertemuan ini sama dengan pertemuan sebelumnya. Siswa sudah faham betul langkahlangkah pembelajaran yang dilakukan. Siswa lebih aktif dalam bertanya jawab dengan guru dan teman kelompoknya.

Pertemuan kelima dilaksanakan pada tanggal 6 April 2017. Pertemuan ini adalah pertemuan terakhir sebelum diadakan pascates pada tanggal 10 April 2017. Materi yang diajarkan adalah dongeng yang berjudul "Kisah Qorun yang Sombong". Pembelajaran berjalan dengan lancar tanpa kendala. Langkah pembelajarannya sama dengan pertemuan sebelumnya

2. Pembelajaran Menyimak dengan Menggunakan Pembelajaran Langsung

Pembelajaran menyimak menggunakan pembelajaran langsung dilakukan oleh guru kelas yang bersangkutan. Pembelajaran di kelas ini waktunya sama dengan kelas yang menggunakan strategi DLTA. Pengambilan data prates dilakukan pada tanggal 13 Maret 2017. Pertemuan ke-1 dilaksanakan pada tanggal 20 Maret 2017 dengan materi dongeng yang berjudul "Kisah Pencuri yang Bertobat".
Pertemuan kedua dilaksanakan pada tanggal 23 Maret 2017 dengan materi dongeng yang berjudul "Kisah Raja Zalim dan Pemuda Shalih". Pertemuan ketiga dilaksanakan pada tanggal 27 Maret 2017 dengan materi dongeng yang berjudul "Kisah Raja Jadi Tukang Kebun". Pertemuan keempat pada tanggal 3 April 2017 dengan materi dongeng yang berjudul "Kisah Si Kusta". Pertemuan terakhir pada tanggal 6 April 2017 dengan dongeng yang berjudul "Kisah Qorun yang Sombong". Pascates dilakukan pada tanggal 10 April 2017 dengan dongeng yang berjudul "Kisah Syeh Abdul Qadir Jaelani”.

\section{Kemampuan Dongeng Siswa}

Menyimak

Kemampuan menyimak dongeng siswa kelas V SDN 6 Singaparna sebelum dilakukan penelitian berada pada kategori cukup. Ratarata skor kemampuan menyimak dongeng di kelas eksperimen adalah 67,20 dan rata-rata skor kemampuan menyimak dongeng kelas kontrol adalah 67,26. Berdasarkan hasil uji normalitas, skor kemampuan menyimak dongeng kelas eksperimen adalah 0,83 lebih besar dari $\alpha=0,05$, maka skor kemampuan menyimak dongeng berdistribusi normal. Adapun Skor kemampuan menyimak dongeng di kelas kontrol adalah 0,69 lebih besar dari $\alpha=0,05$, oleh karena itu skor kemampuan menyimak dongeng di kelas kontrol juga berdistribusi normal. Hasil uji homogenitas skor kemampuan menyimak dongeng kelas eksperimen dan kelas kontrol 
adalah 0,468 lebih besar dari $\alpha=$ 0,05 , dengan demikian maka tidak ada perbedaan kemampuan siswa di kelas eksperimen dan kelas kontrol. Sedangkan berdasarkan hasil uji perbedaan rata-rata skor kemampuan menyimak dongen kelas eksperimen dengan kelas kontrol adalah 0.990 lebih besar dari $\alpha=0,05$ yang berarti bahwa rata-rata skor kemampuan menyimak dongeng kelas eksperimen dan kelas kontrol tidak ada perbedaan.

Setelah dilakukan 5 kali treatment, maka terdapat peningkatan skor kemampuan menyimak dongeng di kelas eksperimen dan kelas kontrol. Di kelas eksperimen, ratarata skor kemampuan menyimak dongeng adalah 84,53 yaitu masuk kategoti baik. Sedangkan rata-rata skor kemampuan menyimak dongeng kelas kontrol adalah 77,55 , yaitu masuk kategori cukup. Berdasarkan hasil uji normalitas, skor kemampuan menyimak dongeng adalah 0,169 lebih besar dari $\alpha=0,05$, dengan demikian maka skor kemampuan menyimak dongeng berdistribusi normal. Untuk kelompok kontrol, hasil uji homogenitas skor kemampuan menyimak dongeng adalah 0,149 lebih besar dari $\alpha=0,05$, dengan demikian maka skor kemampuan menyimak dongeng kelas kontrol berdistribusi normal. Adapun berdasarkan hasil uji homogenitas skor kemampuan menyimak dongeng kelas eksperimen dan kelas kontrol adalah 0,723 lebih besar dari $\alpha=0,05$, dengan demikian maka skor kemampuan menyimak dongeng kelas eksperimen dan kelas kontrol memiliki variansi yang sama. Hasil uji perbedaan rata-rata skor kemampuan menyimak dongeng kelas eksperimen dan kelas kontrol pada $\alpha=0,05$, df $=59$ dan uji (1tailed) maka diperoleh $t_{\text {kritis }}=1,671$ sedangkan thitung $=4,445$, karena thitung $>t_{k r i t i s}$ dan berada di daerah penolakan $\mathrm{H}_{0}$, maka dapat disimpulkan bahwa terdapat perbedaan skor kemampuan menyimak dongeng kelas eksperimen dan kelas kontrol.

Berdasarkan hasil pengujian perbedaan rata-rata gain ternormalisasi (N-Gain) di kelas eksperimen terdapat 4 orang siswa mengalami peningkatan yang tinggi, 26 orang siswa mengalami peningkatan yang sedang, dan tidak ada siswa yang mengalami peningkatan rendah. Sedangkan di kelas kontrol tidak terdapat siswa yang mengalami peningkatan tinggi, 16 orang siswa mengalami peningkatan sedang, dan 15 orang siswa mengalami peningkatan rendah.

\section{SIMPULAN}

Simpulan dari penelitian ini adalah terdapat pengaruh positif strategi Direct Listening Thinking Activity (DLTA) berbantuan media audio visual terhadap kemampuan menyimak dongeng. Hal ini terlihat dari rata-rata skor akhir kemampuan menyimak dongeng di kelas eksperimen dan kelas kontrol. Di kelas eksperimen, rata-rata skor akhirnya adalah 84,53 dan rata-rata skor akhir di kelas kontrol adalah 77,55.

Saran terkait dilaksanaannya penelitian ini adalah guru sebagai 
fasilitator pembelajaran hendaknya pembelajaran dan media terus berinovasi agar terciptanya pembelajaran yang sesuai juga akan pembelajaran yang menyenangkan membuat tujuan pembelajaran lebih bagi siswa. Pemilihan strategi mudah tercapai.

\section{DAFTAR PUSTAKA}

Septiadi, dkk. (2014). Pengaruh Tompkins, G.E. \& Hoskisson, K. strategi the direct listening thinking activity berbantuan media audio terhadap kemampuan menyimak (1991). Language arts: content and teaching strategies. New York: siswa kelas VI. Singaraja: Journal Macmillan Publishing Company.

Membar PGSD Universitas 